DANMARKS GEOLOGISKE UNDERSOGELSE

IV. RAKKE. B D. 4. NR. 8

Geological Survey of Denmark. IV. Series. Vol. 4. No. 8

\title{
Pollen Analysis \\ of the Quaternary Marine Deposits \\ at Tornskov in South Jutland
}

by

Svend Th. Andersen

With 1 Plate

Dansk sammendrag:

Pollenanalyse af de kvartære marine lag

ved Tornskov i Sonderjylland

I kommission hos

C. A. REITZELS FORLAG (JØRGEN SANDAL)

KØBEN HAVN 1963 


\section{Contents}

Abstract............................ 4

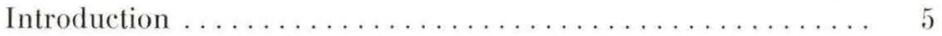

Vegetational History .................... 7

Methods............................. 7

Sources of Error. ........................ 8

Re-deposited Material . . ................... 8

Pollen Zones . . . . . . . . . . . . . . . . . . . . . . . . . . . 10

Ecological Interpretation ........................ 11

Comparison with other Interglacial Deposits . . . . . . . . . 12

Inder Bjergum ..................... 12

Interglacial Fresh-Water Deposits at Harreskov, Starup and Ølgod .......................... 12

Interglacial Holstein Sea Deposits in Northern Germany and the Netherlands ...................... 14

Interglacial Fresh-Water Deposits in Northern Germany, the Netherlands and Poland ..................... 15

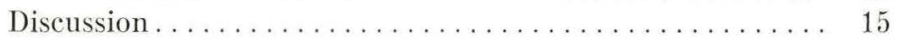

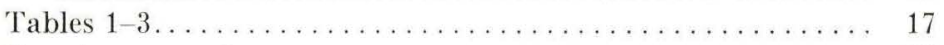

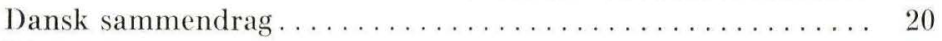

Literature ........................... 22 


\section{Abstract}

At Tornskov $4 \mathrm{~km}$ north of Logumkloster, south Jutland, a Quaternary marine deposit was found at $27-95 \mathrm{~m}$ below the surface. The marine deposit is covered by glacial deposits, which contain a dislocated fragment of the marine deposit. Tertiary deposits occur below $107 \mathrm{~m}$. The deposits were investigated with pollen analysis. Re-deposited pollen is very frequent below $77 \mathrm{~m}$. The layers at $27-77 \mathrm{~m}$ correspond to a major part of an interglacial succession beginning with Betula-Pinus dominance, and continuing with Alnus-Pinus dominance. Picea, Quercus, Ulmus, Carpinus, Abies, Corylus, Taxus and other trees and shrubs are represented with rather low frequencies. The interglacial marine deposit at Tornskov is contemporaneous with the interglacial marine deposit at Inder Bjergum near Ribe, and with deposits of the interglacial Holstein Sea in north Germany and the northern Netherlands, in which there is a similar vegetational development. Pollen diagrams typical of the Holsteinian Interglacial are also known from fresh-water deposits in north Germany, the Netherlands and Poland. The interglacial fresh-water deposits at Harreskov, Starup and Olgod in western Jutland belong to another, presumably older interglacial stage. 


\section{Introduction}

In 1958 the Geological Survey of Denmark carried out a boring at Tornskov $4 \mathrm{~km}$ north of Logumkloster in south Jutland (DGU file nr. 159.243, altitude ab. $22 \mathrm{~m}$, see the map fig. 1), in which a Quaternary marine deposit extending to a considerable depth was encountered. The boring was supervised by Leif Banke Rasmussen. The marine layers contain considerable quantities of foraminifera, which are being investigated in detail by ARNE Bucr (cf. Buch 1963).

The description of the sediments given by Banke Rasmussen is summarized briefly below. The information about the origin of the sediments is based on preliminary results of the examination of the foraminifera by BucH.

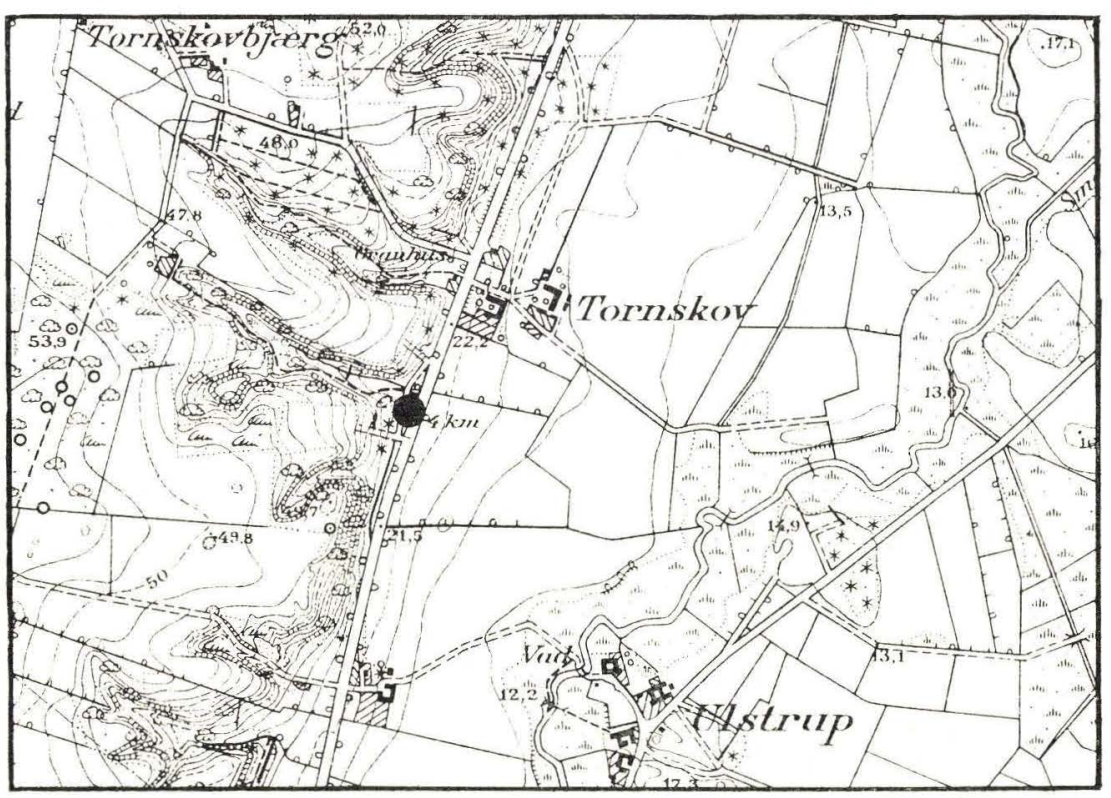

Fig. 1. Section of the map sheet No. 4006 (1:20000) showing the location of the boring near Tornskov. Authorized by the Geodetic Institute of Denmark.

Udsnit af målebordsblad Nr. 4006 (1:20000) visende beliggenheden af boringen ved Tornskov. 


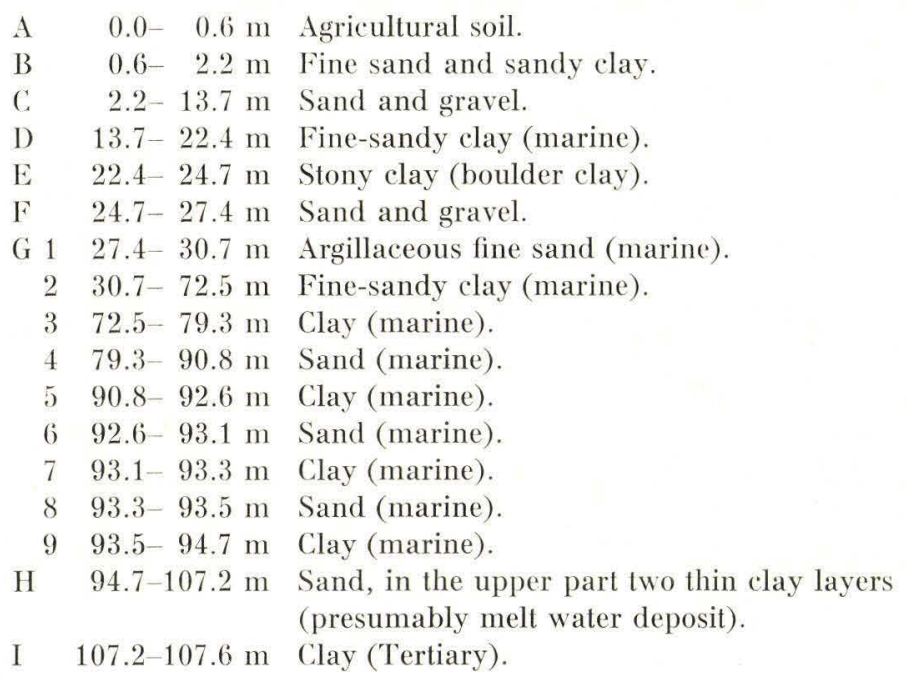

The boring was carried out at the edge of a "hill island" consisting of glacial deposits of the Saalian Glacial (s.l., ef. the map in Milthers 1948). According to the description above, a marine environment is indicated in the sediments at $13.7-$ $22.4 \mathrm{~m}(\mathrm{D})$ and at $27.4-94.7 \mathrm{~m}(\mathrm{G})$. The pollen analyses reported below show that the upper marine sediment is a fragment of the lower marine deposit, presumably dislocated by glacial activity. The lower marine deposit is likely to be undisturbed. The Quaternary marine sediments occupy a deep fiord-like depression of the Tertiary surface (Banke Rasmussen, personal communication).

The Quaternary marine deposits at Tornskov are covered by glacial deposits, and hence must be older than the Eemian Interglacial. Marine interglacial deposits referred to the Penultimate Interglacial (Holsteinian Interglacial) occur in deep borings in the Ribe area and in the vicinity of Esbjerg further north (JESSEN 1922, Nordmann 1928, Buch 1955). All these deposits, including the one encountered at Tornskov, presumably belong to the interglacial Holstein Sea, which is known from occurrences in northwest Germany and the northern Netherlands (see especially Grahle 1936, Brouwer 1949).

According to preliminary results by Buch (cf. BucH 1963), the Quaternary foraminiferal succession represented at Tornskov is similar to the one encountered at Inder Bjergum near Ribe (Buch 1955) and may be divided into a lower Elphidium clavatum-Cassidulina crassa zone $(82-94 \mathrm{~m})$, a middle Elphidium clavatum-Elphidium (Nonion) orbicularis zone (77-81 m), and an upper Elphidium clavatum-Streblus Beccarii zone ( $27-76 \mathrm{~m})$. The zone with Cassidulina crassa indicates cold water conditions, while the zone with Elphidium orbicularis represents an interval of rising temperature, and the zone with Streblus Beccarii suggests conditions similar to the present North Sea (Buch 1955).

The botanical investigation of the deposits constitutes the main subject of this article. 


\section{Vegetational History}

Interglacial marine horizons constitute important guide horizons in Pleistocene stratigraphy. Pollen analysis of such deposits is of great interest because it provides a basis for a correlation between the marine and the continental sequences. Heck (1932), Vermeer-Louman (1934), Woldstedt (1949), Halicki (1951) and von der BRELIE (1954) published pollen diagrams from deposits of the interglacial Eem Sea from northern Germany, the Netherlands and north Poland, which comprise fragments of the development known from pollen diagrams from fresh-water deposits of the same areas. Deposits belonging to the Holstein Sea were examined with pollen analysis by Brouwer (1949, northern Netherlands) and recently by HaLliK (1960, Hummelsbittel near Hamburg). The important pollen diagram published by Hallik (l.c.) shows a sequence, which corresponds to the regetational development recognized in certain fresh-water deposits.

Interglacial marine deposits are thus inviting objects for pollen analysis. Marine deposits may in some cases be excellently suited for this technique, but in other cases difficulties may arise due to poor pollen preservation, irregularities of pollen deposition or the presence of rebedded material.

\section{Methods.}

The marine sediments from the Tornskov boring contained very few macroscopic plant remains; only a few wood fragments, highly modified by pressure, were found (at $28 \mathrm{~m}$, wood of Pinus, and at $31 \mathrm{~m}$, wood of Pinus and a twig of Populus or Salix). There were no diatoms in the untreated samples.

The samples for pollen analysis were extracted from the larger samples obtained during the boring. Only a small amount of material was used (1-2 ccm), and care was taken to extract these samples from the undisturbed parts of the larger samples. Satisfactory samples could not be obtained from the purely sandy parts of the section.

The samples consisted almost exclusively of mineral matter. They were treated chemically as follows,

(1) treatment with cold $\mathrm{HCl}$,

(2) boiling with $10 \% \mathrm{KOH}$ for $6 \mathrm{~min}$. (in water bath), removal of sand by decanting,

(3) boiling with $40 \% \mathrm{HF}$ for $10-15 \mathrm{~min}$, heating with $10 \% \mathrm{HCl} 2$ or 3 times,

(4) boiling with $10 \mathrm{ml}$ acetic anhydride $+1 \mathrm{ml}$ conc. $\mathrm{H}_{2} \mathrm{SO}_{4}$ for $1 \mathrm{~min}$. (in water bath),

(5) staining with fuchsin and mounting in silicone oil according to the procedure in Andersen (1960). 
The organic content was very slight. The pollen was rather awundant, but much crumpled, and the analysis work accordingly rather elaborate. About 500 pollen grains were counted in most of the samples.

The pollen analyses are shown in two diagrams (fig. 2 and plate I), and in the tables 1 and 2. The diagram fig. 2 shows the frequencies for pre-Quaternary pollen and spore types, including all pollen and spore types belonging to plants extinct in northern Europe since the Tertiary (and the Early Pleistocene), as a percentage of the total pollen and spores. Table 1 shows the pollen and spore content of the samples between 77 and $107 \mathrm{~m}$ as a percentage of the total pollen and spores. These pollen spectra contain abundant pre-Quaternary material. The pollen diagram on plate I shows the curves for the most important pollen and spores between 13.7 and $77.0 \mathrm{~m}$. In this diagram the pre-Quaternary pollen and spore types were omitted from the total pollen. A few "local" types also were excluded. Frequencies for Pediastrum also are shown in the pollen diagram. Pollen and spores not shown in this pollen diagram are indicated in table 2.

\section{Sources of Error.}

Fractionation of the pollen rain during transportation in the air may influence the pollen content of marine sediments formed at some distance from the coast. However, there is evidence that the heavy Picea pollen is dispersed just as effectively as Pinus at distances up to $100 \mathrm{~km}$ (Hesselman 1919, von Post 1924, Aario 1940). Mixing by air tubulence thus seems to influence the horizontal dispersal of pollen grains over such distances (see especially the discussion in F EGRI and IvErSEN 1950).

The different floating capacities of pollen grains in water may also introduce a source of error in marine sediments. F.EGR $(1943)$ and FLORIN $(1945,1957)$ found Pinus pollen to be overrepresented in marine sediments from quiet bays, and Fromm (1938) found overrepresentation of Pinus pollen in distal delta deposits from northern Sweden. The Pinus pollen is also more frequent in the deep water sediments from Gullmarsfjord, western Sweden (Fries 1951) than in the nearby lake deposits. Muller (1959) found that fractionation took place during the transportation of pollen by sea currents, resulting in overrepresentation of pollen types with high floating capacity. As the sediment from the boring at Tornskov consists of watertransported material, the Pinus pollen may prove to be somewhat overrepresented compared with lake deposits.

\section{Re-deposited Material.}

Marine sediments consisting principally of derived mineral matter are likely to contain older pollen and spores eroded and deposited together with the mineral matter (Iversen 1936). The secondary fraction can in some cases be calculated and excluded, but even then the presence of secondary pollen is likely to make it impossible to distinguish the finer details of the pollen diagrams (cf. IvErSEn 1943).

The incidence of re-deposited pollen in the Quaternary series at Tornskov is illustrated by the frequencies of the pre-Quaternary pollen and spore types shown in fig. 2. These types dominate the pollen spectrum in the Tertiary clay I and the melt- 


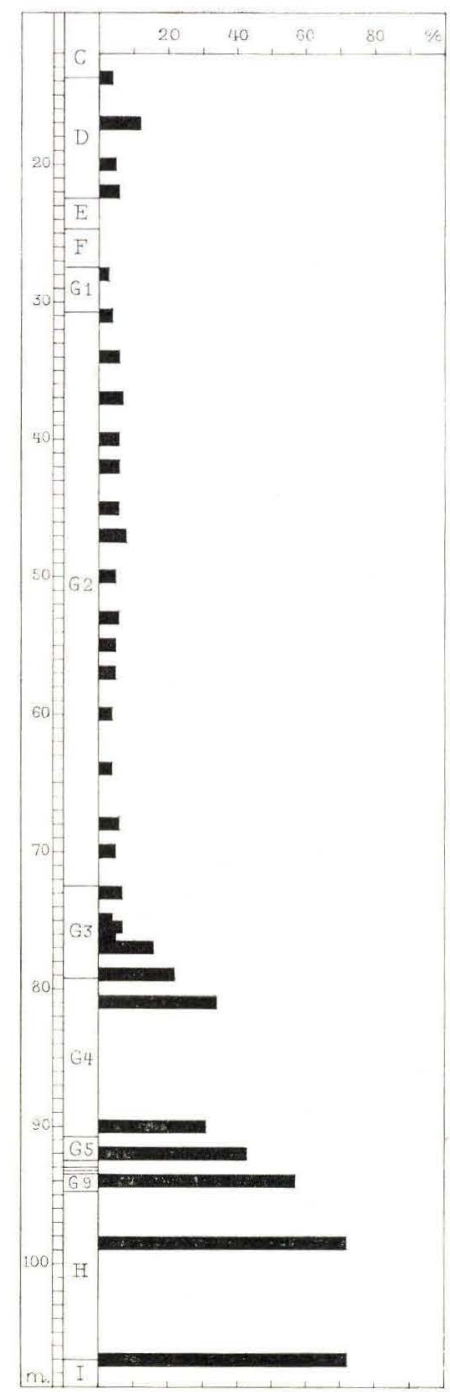

Fig. 2. Frequencies for pre-Quaternary pollen and spore types, as percentage of the total pollen and spores.

Hyppighed af prækvartære pollen-og spore-typer, i procent af alle pollen og sporer.

water deposit $\mathrm{H}(72 \%)$. They occur in the marine deposits $\mathrm{G}$ and $\mathrm{I})$ with varying frequencies. Between 81 and $94 \mathrm{~m}$ the frequency of the pre-Quaternary types is $31-57 \%$. This shows that there is pollen of both Tertiary and Quaternary age. The high frequency of the Tertiary pollen indicates strong contamination with redeposited material, and one may assume that also a good deal of the Quaternary pollen is secondary. This assumption is supported by the fact that pollen of several 
thermophilous plants occurs (see table 1) in spite of the cold conditions indicated by the foraminiferal community (cf. p. 6). However, some primary pollen disseminated from a contemporaneous vegetation may also occur (Pinus?, Betula, Juniperus, herbaceous plants, see table 1). The pre-Quaternary pollen types decrease from $34 \%$ at $81 \mathrm{~m}$ to $5 \%$ at $76 \mathrm{~m}$. This change indicates decreased contamination with re-deposited pollen and increased frequency of primary pollen. It coincides with the temperature increase indicated by the foraminiferal succession, and presumably it was due to increased pollen dissemination from a denser vegetation cover. In fact, the pollen analyses at 77 and $76 \mathrm{~m}$ indicate an early-interglacial Betula-Pinus forest of a pioneer type with relics from forestless vegetation (zone H 1, see below).

Above $77 \mathrm{~m}$ the frequency of the pre-Quaternary pollen types is less than $10 \%$, and so the contamination with re-deposited pollen is low. However, as the subjacent layers may contain primary pollen, their pollen content is unsuitable for a calculation and subtraction of the secondary fraction, but the influence of re-deposited Quaternary pollen on the pollen diagram can only be rather insignificant.

\section{Pollen Zones.}

The pollen diagram from the levels $28-77 \mathrm{~m}$ (plate I) reflects a vegetational development which is clearly interglacial, but of a type not yet described from interglacial sections in Denmark. The following preliminary zones can be distinguished.

Zone H 1 (?-76 m). The zone is characterized by the dominance of Betula pollen. Pinus pollen is fairly frequent. Pollen of Populus, Salix, Juniperus and herbaceous plants is rather common.

Zone H $2(75.7 \mathrm{~m})$. A maximum for Pinus pollen characterizes the zone. The Betula pollen frequency decreases, that of Alnus increases, and there is a small maximum of Fraxinus pollen (6\%). The values for Populus and Juniperus decrease.

Zone $\mathrm{H} 3(75-53 \mathrm{~m})$. Pinus and Alnus pollen is dominant in this zone, the Pinus pollen occurring with a frequency of $30-40 \%$ and the Alnus pollen with a frequency of about $20 \%$. The Betula pollen frequency decreases to about $10 \%$. Pollen of Picea, Quercus and Corylus occurs with frequencies of $5-10 \%$, that of Carpinus with $0.5-1 \%$.

$\mathrm{Z}$ one $\mathrm{H} 4(50-40 \mathrm{~m})$. The zone is similar to the previous one, but the Carpinus frequency increases somewhat (up to nearly $6 \%$ ). Abies pollen appears with a frequency less than $1 \%$.

Zone H $5(37-28 \mathrm{~m})$. The frequency for the Abies pollen increases to about $5 \%$, and the frequency for the Carpinus pollen decreases slightly. The Pinus pollen frequency increases somewhat.

The record is truncated above $28 \mathrm{~m}$ by the gravelly layer $\mathrm{F}$ and the boulder clay E. The argillaceous sand at $13-22.4 \mathrm{~m}$, according to the pollen analyses, is a fragment of the interglacial marine sediment derived from layers corresponding to zone $\mathrm{H} 3$. Presumably it was dislocated by glacial activity. 


\section{Ecological Interpretation.}

There is no clear evidence of aretic or subarctic vegetation at the base of the pollen diagram, presumably because the pollen production was too low compared with the sedimentation of secondary pollen. In zone H 1, the frequent occurrence of Betula, Populus, Salix, Juniperus, Cramineae and Cyperaceae suggests that the forest of that time was of pioneer type with relies from an open-country vegetation like those known from other interglacials and the early Post-glacial.

In zone H 2 Pinus apparently increased at the expense of Betula, and the decrease of light-demanding plants presumably was due to this increased density of the forest.

The ensuing part of the pollen diagram, which comprises the pollen zones $\mathrm{H} 3$ H 5, is rather monotonous. Although the record is truncated upwards, and there are no traces of a climatic deterioration, this development clearly covers a considerable part of an interglacial succession. Characteristic features are the increases in Carpinus and Abies pollen, delimiting in turn zones $\mathrm{H} 4$ and $\mathrm{H} 5$. The general dominance of Pinus pollen contrasts with the rareness of the other forest components except for Alnus. Picea, Quercus, Ulmus, Tilia, Corylus, Taxus and later Carpinus and Abies were present, and we might expect that these trees and shrubs established themselves at the expense of the more light-demanding forest elements. As mentioned on p. 8, the Pinus pollen is probably somewhat overrepresented, but the frequencies for Quercus, Ulmus, Carpinus and Corylus still seem remarkably low. This may mean that the soils were infertile, but the problem can hardly be solved with the present material. Alnus reaches notable frequencies (20-30\%). The pollen of this genus could not be identified at the species level. It conceivably represents Alnus glutinosa, which might have formed extensive carr forest on low-lying ground.

Except for the earliest phases, the climate undoubtedly was temperate, and, due to the rather frequent occurrence of Taxus, Ilex and Myrica, of moist-oceanic type.

Acidophilous plants such as Calluna, Myrica, Pteridium and Sphagnum were apparently quite important, presumably indicating that acid soils with heathy and boggy vegetation began to develop rather early. Salix, Juniperus and Frangula were also fairly abundant.

The pollen of Chenopodiaceae and Plantago maritima recorded rather frequently from zone $\mathrm{H} 1$ and upwards indicates the presence of salt marshes. The Pediastrum colonies present throughout the diagram may have been derived from older deposits, or the colonies may have been transported by water currents from the river mouths.

In summary, the characteristic features of the pollen diagram from the marine interglacial deposit at Tornskov are,

(1) early phases with high frequencies of Belula and Pinus pollen,

(2) high values for Alnus in the rest of the diagram,

(3) rather low values for Picea, Quercus, Ulmus, Fraxinus, Tilia, Corylus and Tuxus throughout,

(4) a phase, in which Carpinus pollen reaches $6 \%$,

(5) a phase, in which Abies pollen reaches $5 \%$. 


\section{Comparison with other Interglacial Deposits}

(for localities, see the map fig. 3)

\section{Inder Bjergum.}

It was mentioned on p. 6 that Quaternary marine deposits similar to those encountered at Tornskov occur in westernmost Jutland northwards to the vicinity of Esbjerg. The disturbed clays exposed near Esbjerg have not yielded pollen analyses with primary pollen, presumably because they were deposited at a time, when the sedimentation of primary pollen still was very low. Samples from the boring Inder Bjergum 2 near Ribe, carried out by the Geological Survey of Denmark in 1932 (cp. Bгсн 1955), did contain pollen, but the samples are too widely spaced for a detailed pollen diagram. Pollen analyses of the available samples are shown in table 3 .

According to Bucu (1.c.), the Quaternary marine series at Inder Bjergum extends from $12 \mathrm{~m}$ to $70 \mathrm{~m}$ below the surface. The foraminifera become frequent above $64 \mathrm{~m}$, and warm conditions prevailed from $43.2 \mathrm{~m}$ upwards (Elphidium clavalum-Streblus Beccarii zone, cf. p. 6). Tertiary pollen is abundant up to $45 \mathrm{~m}$, so these samples must be strongly contaminated with re-deposited material. Betula and herb pollen occurs here with notable frequencies. Pinus pollen is abundant throughout the series with values increasing from 29 to $62 \%$. There is less re-deposited material above $45 \mathrm{~m}$. Here Alnus, Picea and Quercus occur with notable frequencies, accompanied by Ulmus, Fraxinus, Tilia, Carpinus, Corylus and Taxus pollen in smaller quantities, whilst Abies is represented regularly from $28 \mathrm{~m}$. These pollen analyses are therefore similar to the diagram from Tornskov, and so confirm the belief that the interglacial marine deposits in the two areas belong to the same marine horizon.

Chenopodiaceae pollen is constantly present in low frequencies thus indicating deep water deposition rather than salt marsh conditions (cf. Bucr l.c., p. 637). In salt marsh deposits the Chenopodiaceae frequency is much higher (see AvERDIECK 1958).

Interglacial Fresh-Water Deposits at Harreskov, Starup and Ølgod.

Interglacial fresh-water deposits, which pre-date the Eemian Interglacial, are known at Starup and at Harreskov in western Jutland (A. Jessen 1922, Jessen and Mrlthers 1928), and at Ølgod in the same area (Andersen, in print). A. Jessen (l.c.) assumed that the deposit at Starup belongs to the same interglacial stage as the marine deposits from the vicinity of Esbjerg, and Jessen and Milthers (l.c.) also accepted 


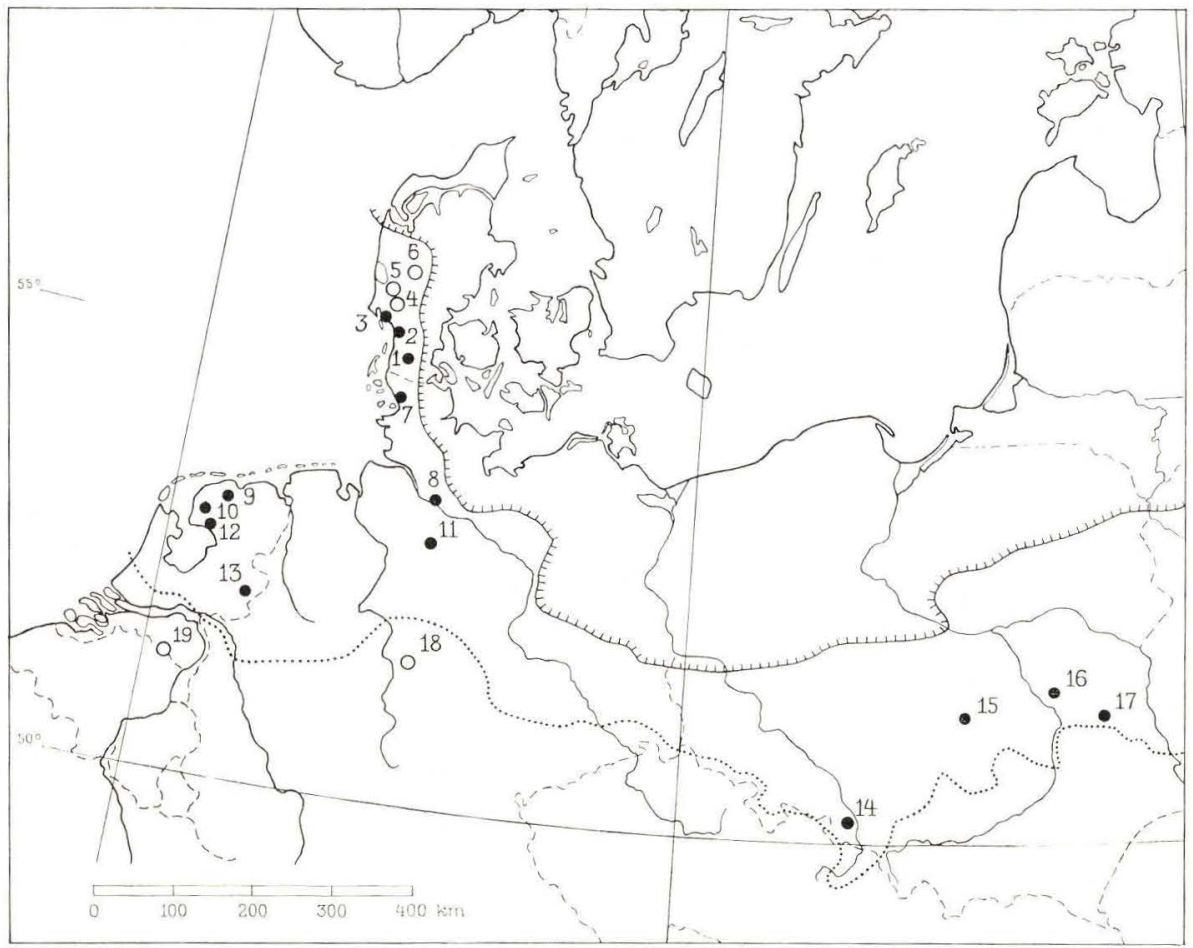

Fig. 3. Interglacial sites mentioned in the text. Holsteinian Interglacial deposit. O deposit of another age. $\cdots \cdot \cdot$ limit of the Saale glaciation. 11|| $\mid$ limit of the Weichsel glaciation.

Lokaliteter med interglaciale lag omtalt i teksten. a aflejring fra Holstein Interglacialtiden. 0 aflejring af anden alder. ..... grænse for Saale-nedisningen. $\|\backslash\|$ grænse for Weichsel nedisningen.
1. Tornskov
2. Inder Bjergum
3. Esbjerg
4. Starup
5. Olgod
6. Harreskov
7. Bredstedt

8. Hummelsbüttel

9. Bergumerheide

10. Sneek

11. Wiechel

12. Bantega

13. Neede

14. Gosciecin

15. Olszewice

16. Wylezin

17. Syrniki

18. Bilshausen

19. Westerhoven

this point of view. Jessen's correlation is open to doubt, and the deposits are not dated with certainty. The deposit at Harreskov is covered by boulder clay (JESSEN and Milthers l.c.), but no moraine cover exists above the interglacial layers at Starup and at Olgod. The covering layers apparently were affected by periglacial erosion during the Weichselian Glacial, and it is not possible to decide whether the deposits were transgressed by one or several glaciations.

Pollen diagrams from the deposits at Harreskov and Starup were published by Jessen and Milthers (l.c.), and the vegetational successions of these interglacials are being re-sludied by the present author. 
According to Jessen and MiLthers (1. c.) the development at Harreskov covers a complete interglacial. Its most significant features are (1) an early Ulmus maximum (38\%), (2) up to $26 \%$ of Quercus, (3) Picea present throughout, (4) rather low Corylus, and (5) absence of Carpinus and Abies. The deposit at Starup only comprises the early vegetational stages of the interglacial. These are identical with the ones known from Harreskov. The vegetational succession represented in the fresh-water deposit at Ølgod is very similar to the one known from Harreskov. In addition to the stages recognized at Harreskov by JESSEN and MrLTHERs (1. c.), the succession at Ølgod contains an early maximum of Taxus. This Taxus maximum has also been recognized in new pollen analyses from Harreskov.

These pollen diagrams are so similar that the deposits must be contemporaneous. They differ significantly from the marine deposits of the Holsteinian Interglacial in South Jutland, and so it is doubtful if they belong to that interglacial.

\section{Interglacial Holstein Sea Deposits in Northern Germany and the Netherlands.}

Pollen diagrams related to the interglacial Holstein Sea deposits are known from Germany and the Netherlands. At Bredstedt, just south of the Danish border, HEсK (1947) found brackish water sediments from the Holstein Sea overlain by fresh-water gyttja. The pollen diagrams from the fresh-water deposits comprise the younger part of an interglacial succession.

Pinus and Betula pollen dominates, and Alnus and Picea are represented with values decreasing from about $20 \%$ to about $5 \%$. Quercus, Tilia, Corylus, Carpinus and Abies are represented at the bottom with low values. This diagram forms a natural upward continuation of the pollen diagram from Tornskov.

The most important pollen diagram from interglacial Holstein Sea deposits is that from Hummelsbüttel near Hamburg recently published by Hallik (1960). The diagram covers nearly $1 \mathrm{~m}$ of fresh-water clay-gyttja and about $2 \mathrm{~m}$ of marine fine-sand, overlying the fresh-water deposit. It is nearly identical with the diagram from Tornskov and has the following phases,

(1) Betula and Pinus dominant, Picea and Alnus very rare, Hippophaë and herb pollen frequent at the bottom,

(2) Alnus dominant, Pinus and Betula decreasing, Picea rather frequent (10-20\%), Quercus, Ulmus, Tilia and Corylus frequencies between 1 and $5 \%$.

(3) Carpinus appears with frequencies of up to $4 \%$, Abies increases to $10-20 \%$ somewhat later.

This series, situated above the present sea-level, records a transgression of the Holstein Sea, which is also shown in the pollen diagram by the appearance of Chenopodiaceae pollen - and by an increase in the Pinus frequencies (from 20 to about $50 \%$ ).

Brouwer (1949) found interglacial Holstein Sea deposits in two borings in the northern part of the Netherlands, at Bergumerheide at 46-62 m below sea level, and at Sneek at 31-42 m below sea level. The pollen diagrams lack detail and seem influenced by various sources of error. Pinus and Alnus pollen dominates, Picea pollen is rather frequent, "Quercetum mixtum" and Corylus obtain only low frequencies, and Abies and Carpinus are represented. The marine deposits are covered by "Keileem", a boulder clay belonging to the Drenthe-Amersfoort substage (GIJZEL, Overweel en Veenstra 1960). 


\section{Interglacial Fresh-Water Deposits in Northern Germany, the Netherlands and Poland.}

HaLliK (1960) published an important pollen diagram from a diatomaceous earth deposit at Wiechel in the Lüneburger Heide. It comprises a major part of an interglacial vegetational succession. HaLLik (l.c.) distinguished the following phases,

(1) Pinus-Betula phase, Salix, Alnus and Picea rare (with a Pinus maximum at the top, resembling zone $\mathrm{H} 2$ at Tornskov),

(2) Pinus-Alnus phase, Quercus, Ulmus, Tilia, Corylus, Picea rare,

(3) Carpinus-Abies phase (Pinus and Alnus dominant).

The pollen diagrams from Tornskov and Hummelsbüttel resemble the pollen diagram from the diatomaceous earth at Wiechel, and although the Pinus values are somewhat higher in the marine deposits, they must belong to the same interglacial stage. Some sites in Northern Germany with less complete pollen diagrams probably belong to the same interglacial (Krefeld, Ohe, Ummendorf, Klieken, Berlin, see Sel.te 1960, Hallik 1.c.). As mentioned by Hallik (l.c.), the pollen diagram from Bantega in the Netherlands (Brouwer 1949) resembles the diagrams from Wiechel and Hummelsbüttel, and the pollen diagram from Neede (van der VherK and F Lonschütz 1953) shows a fragment of a similar development. Abies is represented at some of these sites with frequencies of up to $45 \%$. Most of the deposits mentioned are either covered with till, or have been disturbed by ice-push. Their pollen diagrams differ essentially from those of the Eemian Interglacial, and are placed in the Holsteinian Interglacial by the German and Dutch authors just mentioned.

A great number of pollen diagrams are known from fresh-water deposits of the Masovien I Interglacial in Poland. These deposits were transgressed by the Middle Polish (Saale) glaciation. As mentioned by Hallik (1.c.), the diagrams closely resemble those of the Holsteinian Interglacial of northern Germany and the Netherlands. Pollen of Quercus, Ulmus, Tilia and Corylus is rare, Carpinus and Abies pollen increases to $20-50 \%$ in the upper part, and Alnus and Pinus pollen is common ${ }^{1}$ ).

\section{Discussion.}

Interglacial fresh-water and marine deposits with pollen diagrams similar to that from Tornskov thus oceur in northern Germany, the Netherlands and Poland. Their pollen diagrams represent the typical vegetational succession of the Holsteinian Interglacial (cp. HaLLiK 1960).

As mentioned on p. 14, the pollen diagrams from the limnic deposits at Harreskov, Starup and Olgod in western Jutland differ so essentially from those of the marine

1) Brelie, Kilpper und Teichuüller (1959) found macrofossils and pollen of Pterocarya cf. fraxinifolia Spach. in a peat deposit at Frimmersdorf near Köln which they referred to the Holsteinian Interglacial. Pterocarya pollen also was recorded from Masovien I Interglacial sites in Poland (Środoń 1957, Sobolewska 1956 b, STAChurska 1957), in the Carpinus-Abies zone, where it is undoubtedly primary. Pollen of Pterocarya type was also recorded at Tornskov, at the following levels, $28 \mathrm{~m}: 0.2 \%, 42 \mathrm{~m}: 0.2 \%$, $45 \mathrm{~m}: 0.2 \%, 53 \mathrm{~m}: 0.2 \%, 55 \mathrm{~m}: 0.2 \%, 57 \mathrm{~m}: 0.2 \%, 79 \mathrm{~m}: 0.3 \%, 81 \mathrm{~m}: 1.2 \%, 90 \mathrm{~m}$ : $0.5 \%, 92 \mathrm{~m}: 0.2 \%, 94 \mathrm{~m}: 0.7 \%, 98.5 \mathrm{~m}: 2.0 \%, 107 \mathrm{~m}: 0.7 \%$. Thus it is most frequent helow the $80 \mathrm{~m}$ level where there are many pre-Quaternary pollen and spore types, and so it is most likely to be secondary at this site. 
deposits in southwest Jutland, that it is doubtful if they belong to the same interglacial. A survey of the maximum percentages of various important genera in the most representative pollen diagrams mentioned above is shown below. The quality of these pollen analyses varies somewhat. The pollen diagrams from the Netherlands do not show percentages for the "Quercetum mixtum" components, and Taxus pollen is only recorded in a few of the diagrams. However, it is clear that Quercus and Ulmus obtain much higher percentages at Harreskov and at Ølgod than at the other sites, and the Taxus-frequencies recorded at Tornskov and at Gosciecin are much lower than the figure recorded at Ølgod. Hence, although more detailed pollen diagrams are desirable, the discrepancy noticed between the pollen diagrams from HarreskovOlgod and the one from Tornskov obviously extends to the other Holsteinian Interglacial diagrams from Northern Europe.

\begin{tabular}{|c|c|c|c|c|c|c|c|c|c|c|}
\hline $\begin{array}{l}\text { Maximum } \\
\text { percentage }\end{array}$ & 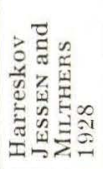 & $\begin{array}{l}\text { D } \\
\text { on } \\
0\end{array}$ & $\begin{array}{l}\frac{3}{3} \\
\frac{9}{5} \\
0 \\
0 \\
0\end{array}$ & 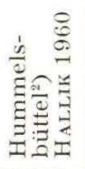 & 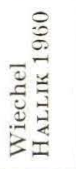 & 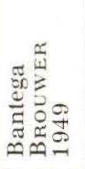 & 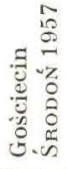 & 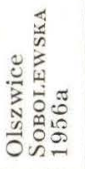 & 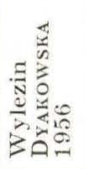 & 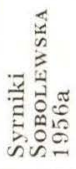 \\
\hline Quercus. & 26 & 39 & 10 & 7 & 9 & · & 9 & 7 & 4 & 13 \\
\hline Ulmus..... . . & 38 & 35 & 2 & 2 & 4 & $\cdot$ & 4 & 2 & 2 & 6 \\
\hline "Q. M." .... & 48 & 58 & 15 & 7 & 10 & 15 & 13 & 9 & 8 & 13 \\
\hline Carpinus.... & $\cdot$ & 0.2 & 7 & 4 & 15 & 3 & 16 & 26 & 22 & 25 \\
\hline Abies........ & . & 0.1 & 6 & 16 & 4 & 6 & 19 & 33 & 42 & 23 \\
\hline Picea ....... & 28 & 10 & 9 & 21 & 13 & 25 & 26 & 12 & 29 & 34 \\
\hline $\begin{array}{l}\left.\text { Corylus }^{1}\right) \ldots \\
\left.\text { Taxus }^{1}\right) \ldots\end{array}$ & $\begin{array}{cc} & 49 \\
& 3\end{array}$ & $\begin{array}{r}20 \\
102\end{array}$ & $\begin{array}{l}9 \\
8\end{array}$ & $\begin{array}{l}15 \\
3\end{array}$ & $\begin{array}{c}28 \\
3\end{array}$ & $\begin{array}{l}6 \\
\left.{ }_{3}\right)\end{array}$ & $\begin{array}{l}12 \\
12\end{array}$ & $\begin{array}{c}14 \\
\left.{ }_{3}\right)\end{array}$ & $\begin{array}{l}8 \\
\left.{ }^{3}\right)\end{array}$ & $\begin{array}{l}24 \\
3\end{array}$ \\
\hline
\end{tabular}

1) Considered outside the pollen totals. ") Marine deposits. ${ }^{3}$ ) Not counted.

The age of the Harreskov-Starup-Olgod deposits remains uncertain. Somewhat similar pollen diagrams are known from the interglacial deposits at Bilshausen, Unter Eichsfeld, in Germany (Lüttig and ReIN 1954), and at Westerhoven in the Netherlands (ZaGwiJn and Zonneveld 1956). They have been referred to the "Cromerian Interglacial" in the general chronology of northern Europe. However, as these diagrams are rather incomplete, this problem has yet to be solved. 
Table 1. Tornskov. Pollen analyses at the levels $77-107.3 \mathrm{~m}$. Pollenanalyser fra niveauerne $77-107.3 \mathrm{~m}$.

\begin{tabular}{|c|c|c|c|c|c|c|c|c|}
\hline $\begin{array}{c}\text { Stratum } \\
\text { Depth, m }\end{array}$ & $\begin{array}{c}\mathrm{I} \\
107.3\end{array}$ & $\begin{array}{c}\mathrm{H} \\
98.5\end{array}$ & $\begin{array}{c}\text { G } 9 \\
94\end{array}$ & $\begin{array}{l}\text { G } 5 \\
92\end{array}$ & $\begin{array}{c}\text { G } 4 \\
90\end{array}$ & $\begin{array}{l}\text { G } 4 \\
81\end{array}$ & $\begin{array}{c}\text { G } 3 \\
79\end{array}$ & $\begin{array}{l}\text { G } 3 \\
77\end{array}$ \\
\hline Carpinus................. & . & 0.5 & 0.3 & 0.2 & 0.2 & 1 & 0.3 & . \\
\hline Quercus . . . . . . . . . . . . . & . & 1 & 0.3 & 0.2 & 0.6 & 1 & 2 & 2 \\
\hline Ulmus. . . . . . . . . . . . . . & 0.3 & 0.5 & . & 0.8 & 0.9 & 0.4 & · & 0.8 \\
\hline 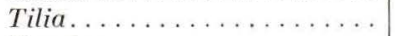 & 0.7 & . & 0.3 & . & 0.1 & $\cdot$ & 0.3 & 0.1 \\
\hline Fraxinus . . . . . . . . . . . & . & & . & 0.2 & 0.1 & . & 2 & 1 \\
\hline Alnus $\ldots \ldots \ldots \ldots \ldots \ldots$ & 1 & 3 & 4 & 9 & 10 & 8 & 6 & 5 \\
\hline 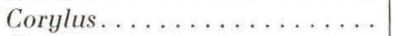 & 1 & . & 0.3 & 1 & 1 & 0.8 & 1 & 1 \\
\hline Ilex................. & 1 & . & 0.3 & 0.2 & 0.4 & 0.4 & 1 & 0.2 \\
\hline Рiceа & 4 & 5 & 4 & 3 & 4 & 2 & 1 & 1 \\
\hline Pinus (silvestris type) . . . . . . & 13 & 5 & 15 & 20 & 19 & 26 & 22 & 23 \\
\hline Betula ............. & 2 & 4 & 3 & 7 & 7 & 13 & 23 & 29 \\
\hline Populus ................... & . & . & . & $\cdot$ & . & $\cdot$ & . & 0.3 \\
\hline Juniperus. . . . . . . . . . . . . & 1 & 0.5 & . & 0.8 & 0.4 & 0.4 & 1 & 2 \\
\hline Salix $\ldots \ldots \ldots \ldots \ldots \ldots$ & & . & & 0.4 & . & $\cdot$ & 0.6 & 1 \\
\hline Frangula $\ldots \ldots \ldots \ldots \ldots$ & . & . & & . & 0.6 & . & . & 0.1 \\
\hline Myrica $\ldots \ldots \ldots \ldots \ldots \ldots$ & 0.3 & . & 0.7 & 0.4 & 0.2 & $\cdot$ & . & . \\
\hline Calluna $\ldots \ldots \ldots \ldots \ldots$ & . & 0.5 & 0.7 & 0.2 & 2 & 0.4 & 0.6 & 0.2 \\
\hline Other Ericales............. & 1 & 1 & 1 & 2 & 2 & 1 & 0.6 & 1 \\
\hline Herbaceous plants, total.... & 0.3 & 2 & 2 & 4 & 4 & 3 & 9 & 11 \\
\hline Gramineae $\ldots \ldots \ldots \ldots \ldots$ & 0.3 & 0.5 & 2 & 2 & 2 & 2 & 5 & 5 \\
\hline Cyperaceae................ & . & 0.5 & & 2 & 1 & . & 4 & 3 \\
\hline Artemisia $\ldots \ldots \ldots \ldots \ldots$ & & . & . & . & 0.5 & 0.4 & 0.6 & 0.2 \\
\hline Caryophyllaceae $\ldots \ldots \ldots \ldots$ & . & 0.5 & . & . & . & . & . & . \\
\hline Chenopodiaceae........... & . & . & . & . & 0.2 & . & . & . \\
\hline Humulus ............. & . & . & . & . & . & . & . & 0.2 \\
\hline Liguliflorae $\ldots \ldots \ldots \ldots \ldots$ & . & . & . & . & 0.1 & . & . & . \\
\hline Lycopodium . . . . . . . . . . . . & . & 1 & . & . & . & . & . & . \\
\hline Pteridium . . . . . . . . . . . . & . & . & . & . & 0.3 & & & . \\
\hline Rumex acet. type........... & . & . & . & . & . & . & . & 0.3 \\
\hline Thalictrum............. & . & . & . & & . & 0.4 & . & . \\
\hline Tubuliflorae............... & - & . & . & . & . & $\cdot$ & . & 0.2 \\
\hline Osmunda $\ldots \ldots \ldots \ldots \ldots$ & . & . & . & . & 0.4 & 0.4 & . & 0.2 \\
\hline Typha-Sparganium......... & . & . & . & . & $\cdot$ & $\cdot$ & 0.3 & 0.1 \\
\hline Thelypteris type ........... & 2 & 1 & 2 & 1 & 4 & 2 & 3 & 2.4 \\
\hline Sphagnum.............. & 0.7 & 3 & 6 & 9 & 11 & 4 & 4 & 4 \\
\hline $\begin{array}{l}\text { Pre-Quaternary pollen and } \\
\text { spore types ............. }\end{array}$ & 72 & 72 & 57 & 43 & 31 & 34 & 22 & 16 \\
\hline Total ................... & 300 & 205 & 296 & 507 & 775 & 248 & 312 & 96.3 \\
\hline Pediastrum................ & . & 0.5 & 2 & 3 & 3 & 7 & 3 & 4 \\
\hline
\end{tabular}




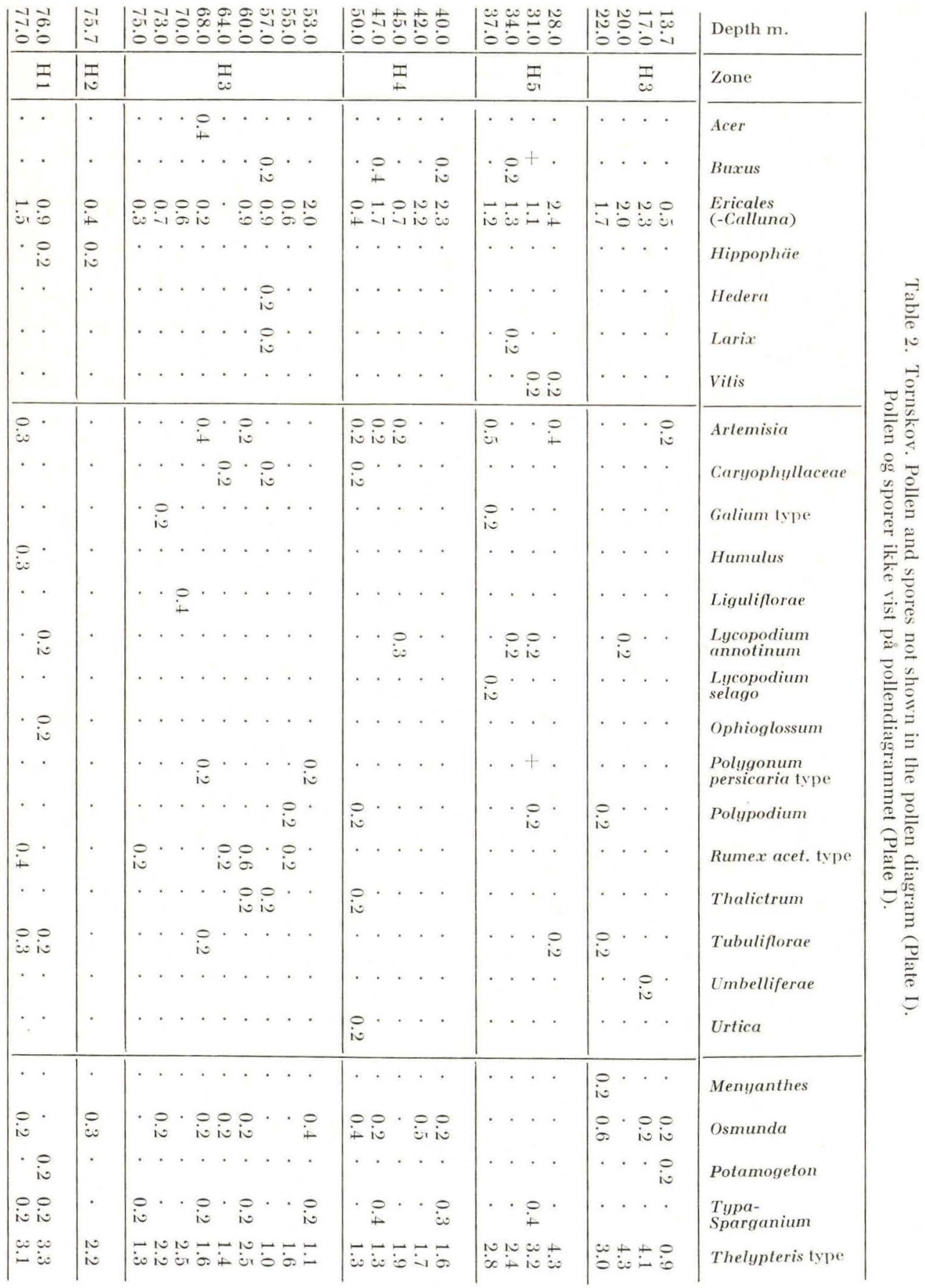


Table 3. Inder Bjergum. Pollen analyses.

\begin{tabular}{|c|c|c|c|c|c|c|c|c|c|}
\hline Depth, m & $\begin{array}{r}57.5 \\
-62.5\end{array}$ & $\begin{array}{r}48.5 \\
-54.5\end{array}$ & 45.0 & 41.25 & 37.0 & 28.0 & 21.0 & 14.5 & $12-13$ \\
\hline Pinus .............. & 29 & $3: 3$ & 15 & 51 & 伡 & 37 & 50 & 62 & 50 \\
\hline Betula .............. & $2 \cdot 2$ & 33 & 25 & 12 & 9 & 5 & 6 & 3 & 7 \\
\hline Alnus $\ldots \ldots \ldots \ldots \ldots$ & 16 & 13 & 6 & 21 & 16 & 14 & 13 & 10 & 19 \\
\hline Picea ............... & 6 & 2 & 2 & 4 & $\ddot{2}$ & 5 & 6 & 7 & 7 \\
\hline Quercus ............... & 4 & 3 & 1 & 3 & 6i & 9 & $: 3$ & 3 & 2 \\
\hline Ulmus . . . . . . . . . . . . . . & 2 & 1 & 1 & 0.5 & 1 & 0.4 & 1 & 0.4 & 1 \\
\hline Fraxinus . . . . . . . & . & . & . & 1 & 2 & 2 & 1 & 0.4 & 0.6 \\
\hline Tilia............... & 1 & . & . & . & 0.4 & 0.4 & . & $\cdot$ & 0.6 \\
\hline Carpinus.............. & 1 & . & 1 & $\cdot$ & 1 & 0.1 & $0 . \overline{5}$ & 0.8 & 0.6 \\
\hline Abies................. & 2 & . & . & 0.5 & . & 0.8 & 2 & 3 & 1 \\
\hline Salix . . . . . . . . & . & 1 & 2 & 0.5 & 0.8 & . & . & $\cdot$ & 0.6 \\
\hline Juniperus............... & 3 & 1 & . & . & . & 0.4 & 0.5 & 0.4 & · \\
\hline Corylus... . . . . . . . . & . & 1 & . & 3 & $\overline{5}$ & 1 & 2 & 0.4 & . \\
\hline 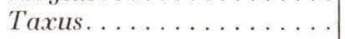 & . & . & . & 1 & (i & j & 2 & 4 & 0.6 \\
\hline Buxus............... & . & $\cdot$ & $\cdot$ & $\cdot$ & $\cdot$ & . & . & 0.4 & $\cdot$ \\
\hline Ilex................ & . & 0.5 & 0.5 & 0.5 & 0.4 & . & . & $\cdot$ & . \\
\hline Frangula ............. & . & $\cdot$ & 0.5 & 0.5 & 0.4 & 0.4 & . & $\cdot$ & . \\
\hline Myrica .............. & . & . & $\cdot$ & $\cdot$ & 0.4 & . & $\cdot$ & 0.4 & $\cdot$ \\
\hline Calluna ............... & 3 & . & . & 0.5 & 2 & 2 & 0.5 & $\cdot$ & 0.6 \\
\hline Other Ericales.......... & 5 & 1 & 2 & 1 & $\cdot$ & 1 & 2 & 0.8 & 2 \\
\hline $\begin{array}{l}\text { Tolal of herbaceous } \\
\text { plants ............ }\end{array}$ & 14 & 7 & 15 & 1 & 5 & 5 & 12 & 4 & 6 \\
\hline Gramineae ............ & 6 & 3 & 6 & 0.5 & 2 & 2 & 2 & 2 & 2 \\
\hline Cyperaceae............ & 1 & 4 & 6 & 1 & 2 & . & 4 & 0.8 & 1 \\
\hline Pteridium. . . . . . . . . . . & · & $\cdot$ & 1 & . & 1 & 3 & 5 & . & 0.6 \\
\hline Chenopodiaceae......... & . & $0 . \overline{5}$ & 0.5 & . & 0.4 & 0.4 & 0.5 & 0.8 & · \\
\hline Plantago maritima ...... & . & $\cdot$ & 0.5 & . & $\cdot$ & $\cdot$ & 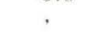 & 0.4 & 0.6 \\
\hline Artemisia . . . . . . . . & . & 0.5 & 0.5 & · & . & . & , & . & . \\
\hline Liguliflorae . . . . . . . . & . & $\cdot$ & $\cdot$ & . & . & · & . & · & 1 \\
\hline Lycopodium selago ...... & . & . & 0.5 & . & . & . & . & . & . \\
\hline Polypodium ........... & . & $\cdot$ & $\cdot$ & $\cdot$ & . & · & . & $\cdot$ & 1 \\
\hline 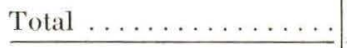 & 125 & 219 & 198 & 211 & 266 & 255 & 199 & 252 & 165 \\
\hline Osmunda . . . . . . . . & · & 0.5 & $\cdot$ & 0.5 & . & 0.8 & . & . & . \\
\hline Thelypteris type ....... & 5 & 3 & 2 & 2 & 2 & 2 & 1 & 3 & 4 \\
\hline Sphagnum . . . . . . . . & 21 & 9 & 10 & 4 & 5 & 2 & 3 & 4 & 0.6 \\
\hline Pediastrum............. & 14 & 5 & 10 & 5 & 1 & 0.8 & 3 & 1 & 2 \\
\hline $\begin{array}{l}\text { Pre-Quaternary pollen } \\
\left.\text { and spore types }{ }^{1}\right) \ldots .\end{array}$ & 36 & 30 & 28 & 10 & 4 & 9 & 12 & 10 & 19 \\
\hline
\end{tabular}

1) Per cent of all pollen and spores. 


\title{
Dansk sammendrag
}

\author{
Pollenanalyse af de kvartare marine lag ved \\ Tornskov i Sonderjylland
}

I 1958 udforte DGU en boring i Tornskov ved Logumkloster (fig. 1), hvorved kvartære marine lag af betydelig tykkelse blev påtruffet. Profilbeskrivelsen, der støtter sig på iagttagelser af Leir Banke Rasmussen og Arne Buch, kan opsummeres således:

$$
\begin{array}{lrl}
\text { A-C } & 0.0-13.7 \mathrm{~m} \text { Sand- og gruslag. } \\
\text { D } & 13.7-22.4 \mathrm{~m} \text { Marint finsandet ler. } \\
\text { E } & 22.4-24.7 \mathrm{~m} \text { Moræneler. } \\
\text { F } & 24.7-27.4 \mathrm{~m} \text { Sand- og gruslag. } \\
\text { G } & 27.4-94.7 \mathrm{~m} \text { Marine ler- og sandlag. } \\
\text { H } & 94.7-107.2 \mathrm{~m} \text { Smeltevandssand. } \\
\text { I } & 107.2-107.6 \mathrm{~m} \text { Tertiært ler. }
\end{array}
$$

Boringen er udfort i kanten af en bakkeo. Den øvre marine horisont (D) er ifolge pollenanalyserne et brudstykke af den nedre marine horisont, og udgør åbenbart en flage disloceret ved isvirksomhed. Den nedre marine horisont $(G)$ er sandsynligvis uforstyrret $\mathrm{og}$ indtager en dyb sænkning i den tertiære overflade. Den er sandsynligvis samtidig med de marine lag ved Ribe og Esbjerg, der henregnes til Næstsidste Interglacialtid (Holstein Interglacialtid). Ifølge Buchs undersøgelser indeholder den marine serie en foraminifersukcession, som ligner den han har undersøgt ved Inder Bjergum (Buch 1955, 1963).

Resultaterne af pollenanalyserne er vist i fig. 2 og plate I, samt i tabel $1 \mathrm{og} 2 . \mathrm{Om}$ lejret pollen forekommer hyppigt i de nederste kvartære lag (80-94 m), som er afsat i et koldt tidsrum med ringe plantedække. Ved 77-80 m aftager hyppigheden af omlejret pollen, hvilket sandsynligvis skyldes, at pollen fra den samtidige vegetation gør sig stærkere gældende. Pollendiagrammet på plate I omfatter kun lagene 13.7$77.0 \mathrm{~m}$, hvor forureningen med omlejret pollen er af ret ringe betydning. Det repræsenterer en betydelig del af en interglacialudvikling, som ikke tidligere er kendt fra Danmark. Pollenzonerne H 1-5 er beskrevet kort på s. 10. De første pollenzoner ( $\mathrm{H} 1 \mathrm{og}$ H 2 ) repræsenterer birke-fyrreskov af pionertype, som typisk udgør de første stadier af en interglacial skovudvikling. De efterfølges af 3 pollenzoner (H 3-H 5), som præges af fremherskende Alnus- og Pinuspollen, mens andre træer og buske som Betula, Picea, Quercus, Ulmus, Corylus, Taxus o. a. kun opnår ret lave værdier. I pollenzone $\mathrm{H} 4$ findes et lille maksimum af Carpinuspollen og $\mathrm{i}$ zone $\mathrm{H} 5$ et tilsvarende af Abiespollen. Serien afbrydes af en diskordans ved $24.7 \mathrm{~m}$. Den ovre marine horisont (D) tilhører pollenzone $\mathrm{H} 3$. 
Nogle pollenanalyser fra boringen ved Inder Bjergum (Buch 1955) er anfort (se tabel 3). I 12-45 m dybde afspejles i grove træk en udvikling svarende til den, der er konstateret ved Tornskov.

Pollendiagrammet fra Tornskov sammenlignes med pollendiagrammer fra Harreskov og Starup henfort til Næstsidste Interglacialtid af Jessen og Milthers (1928) samt den nye lokalitet ved Olgod. Vegetationsudviklingen fra disse tre ferskvandsforekomster stemmer udmærket overens. Den adskiller sig tydeligt fra Eem Interglacialtiden, men ogsaa fra udviklingen kendt fra Tornskov.

Pollendiagrammet fra Tornskov stemmer udmærket med pollendiagrammer fra Holsteinhavets aflejringer ved Hamborg (HALLIK 1960) og i Holland, samt med pollendiagrammer fra samtidige ferskvandsaflejringer i Nordtyskland, Holland og Polen. Denne Vegetationsudvikling er typisk for Holstein Interglacialtiden (Næstsidste Interglacialtid), som ligger mellem Elster og Saale Glacialtiderne. Ferskvandsaflejringerne fra Harreskov, Starup og Olgod må sandsynligvis henfores til en endnu xldre interglacialtid. 


\section{Literature}

Aario, L., 1940. Waldgrenzen und subrezente Pollenspektren in Petsamo Lapland. Acad. Scient. Fenn., Ann., A, 14, 8. Helsinki.

Andersen, S. T., 1960. Silicone oil as a mounting medium for pollen grains. Danm. Geol. Unders., IV. R., 4, 1, København.

- in print. Interglacial plant successions in the light of environmental changes. INQUA. VI. Congress, Warszawa 1961.

Averdieck, F. R., 1958. Pollen vom Chenopodiaceen-Typ im Flöz Frimmersdorf - ein Hinweis auf seine strandnahe Entstehung. Fortschr. Geol. Rheinl. und Westfalen, 1. Krefeld.

Brelie, G. von Der, 1954. Transgression und Moorbildung im letzten Interglazial. Geol. Staatsinst. Hamburg, 23. Hamburg.

Brelie, G. von der, Kilpper, K., und Teichmüller, R., 1959. Das Pleistozän-Profil von Frimmersdorf an der Erft. Fortschr. Geol. Rheinl. und Westfalen, 4. Krefeld.

Brouwer, A., 1949. Pollenanalytisch en geologisch onderzoek van het onder- en middenpleistocaen van Noord Nederland. Leidse Geol. Med., 14 B. Leiden.

Buch, A., 1955. De marine interglaciale Lag ved Inder Bjergum. Dansk Geol. Foren., Medd., 12. København.

- 1963. Marine kvartæraflejringers foraminiferfauna i Danmark. Dansk Geol. Foren., Medd., 15, 240. København.

Dyakowska, J., 1956. Pleistocene profile from Wylezin (Central Poland). (Summary). Inst. Geol., Biul., 100. Warszawa.

Fæari, K., 1943. Studies on the Pleistocene of Western Norway. III. Bomlo. Bergens Mus. Årbok, Naturv. Rekke, 8. Bergen.

Fegri, K., and Iversen, J., 1950. Text-book of modern pollen analysis. Kobenhavn.

FLorin, M.-B., 1945. Skärgårdstall och "strandskog" i västra Södermanlands pollendiagram. Stockh. Högsk. Geol. Inst., Medd., 73. Stockholm.

- 1957. Insjöstudier i Mellansverige. Acta Phyt. Suec., 38. Uppsala.

Fries, M., 1951. Pollenanalytiska vittnesbörd om senkvartär vegetationsutveckling, särskilt skogshistorie, i nordvästra Götaland. Acta phyt. Suec., 29. Uppsala.

Fromm, E., 1938. Geokronologisch datierte Pollendiagramme und Diatomeenanalysen aus Ångermanland. Geol. Fören. Stockh., Förhandl., 60. Stockholm.

Gijzel, P. van, Overweel, C. J., en Veenstra, H. J., 1960. Geological investigations of boulder-clay of E. Groningen. Leidse Geol. Med., 24. Leiden.

Grahle, H.-O., 1936. Die Ablagerungen der Holstein-See (Mar. Intergl. I), ihre Verbreitung, Fossilführung und Schichtfolge in Schleswig-Holstein. Preuss. Geol. Landesanst., N. F., 172. Berlin.

Halickı, B., 1951. The Baltic Sea during the Upper Pleistocene. (Summary). Acta Geol. Pol., 2. Warszawa.

Hallik, R., 1960. Die Vegetationsentwicklung der Holstein-Warmzeit in Nordwestdeutschland und die Alterstellung der Kieselgurlager der südlichen Luineburger Heide. Deutsch. Geol. Ges., Zeitschr., 112. Hannover.

Нвск, H.-L., 1932. Die Eem- und ihre begleitenden Interglazial-Ablagerungen bei Oldenbüttel in Holstein. Preuss. Geol. Landesanst., Abh., N. F., 140. Berlin.

- 1947. Der altinterglaziale Haffsee bei Bredstedt in Nordfriesland. Geol. der Meere und Binnengew., 7 .

Hesselman, H., 1919. Beobachtungen über die Verbreitungsfähigkeit des Waldbaumpollens. Statens Skogsforsöksanst., Medd., 16. Stockholm. 
Iversen, J., 1936. Sekundäres Pollen als Fehlerquelle. Eine Korrektionsmethode zur Pollenanalyse minerogener Sedimente. Danm. Geol. Unders., IV. R., 2, 15. København.

- 1943. Nordisk kvartärgeologiskt möte. Geol. Fören. Stockh., Förhandl., 69. Stockolm.

Jessen, A., 1922. Beskrivelse til det geologiske Kortblad Varde. Danm. Geol. Unders., I. R., 14. København.

Jessex, K., and Mrlthers, V., 1928. Stratigraphical and paleontological studies of interglacial fresh-water deposits in Jutland and Northwest Germany. Danm. Geol. Unders., II. R., 48. Kobenhavn.

Lëttıg, G., und Reın, U., 1954. Das Cromer-(Güz/Mindel)Interglazial von Bilshausen (Unter Eichsfeld). Geol. Jahrb., 70. Hannover.

Minthers, V., 1948. Det danske Istidslandskabs Terrenformer og dets Opstaaen. 1)anm. Geol. Unders., III. R., 28. Kobenhavn.

Mulcer, J., 1959. Palynology of recent Orinoco delta and shelf sediments. Micropaleontology, 5 .

Nordmans, V., 1928. La position stratigraphique des dépots d’Eem. Danm. Geol. Unders., II. R., 47. Kobenhavn.

Post, L. von, 1924. Ur de sydsvenska skogernas regionale historia under postarktisk tid. Geol. Fören. Stockh., Förhandl., 46. Stockholm.

Sisle, W., 1960. Das Interglazial von Praschnitz. Geol. Jahrb., 77, Hannover.

Sobolewska, M., 1956 a. Pleistocene vegetation of Syrniki on the river Wieprz. (Summary). Inst. Geol., Biul., 100. Warszawa.

Sobolewska, M., 1956 b. Pollen analysis of the interglacial deposits of Olszewice on the river Wieprz. (Summary) Inst. Geol., Biul., 100. Warszawa.

Srodoń, A., 1957. Interglacial flora from Goseiecin near Kozle (Sudeten Foreland). (Summary). Inst. Geol., Biul., 118. Warszawa.

Stachurska, A., 1957. Interglacial flora from Wlodowa on the Bug river (Lublin Upland). (Summary). Inst. Geol., Biul., 118. Warszawa.

Vermeer-Loumax, C. G., 1934. Pollenanalytisch onderzoek van den westnederlandschem bodem. Amsterdam.

VLERK, I. M. VAN DER, and FLorschütz, F., 1953. The palaeontological base of the subdivision of the Pleistocene in the Netherlands. Koninkl. Nederl. Akad. Wetensch., Verhandl., Afd. Natuurk., 1. R., 20. Amsterdam.

Woldstedt, P., 1949. Über die stratigraphische Stellung einiger wichtigen Interglazialbildungen im Randgebiet der nordeuropäischen Vergletscherung. Deutsch. Geol. Ges., Zeitschr., 99. Hannover.

ZagwiJn, W. H., and Zonneveld, J. I. S., 1956. The interglacial of Westerhoven. Geol. en Mijnb., N.S., 20. Leiden. 
Denne bog er sat med Monotype Fridericus Antiqua og trykt i 1500 eksemplarer på Andelsbogtrykkeriet i Odense. Papir: Kunsttryk, 125 g, fra De forenede Papirfabrikker. 
Plate I.
Pollen diagram. Tornskov.

A. Total diagram. B. Curves for pollen and spores included in the pollen total. Black
Shouettes indicate percentages, white silhouettes percentages exaggerated by $10 \times$ silhouettes indeate percentages, white silhouettes percentages exaggerated by $10 x$.
C. Curves for microfossils not included in the pollen total. A. Totaldiagram. B. Kurver for pollen o g g sorer indregnet i pollensummen. Sorte
silhouetter viser procenter, hvide silhouetter procenter overdrevet $10 \times$. C. Kurver for mikrofossiler ikke indregnet i pollensummen.

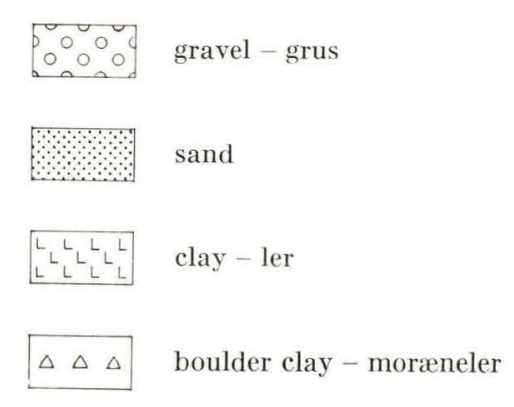

TORNSKOV

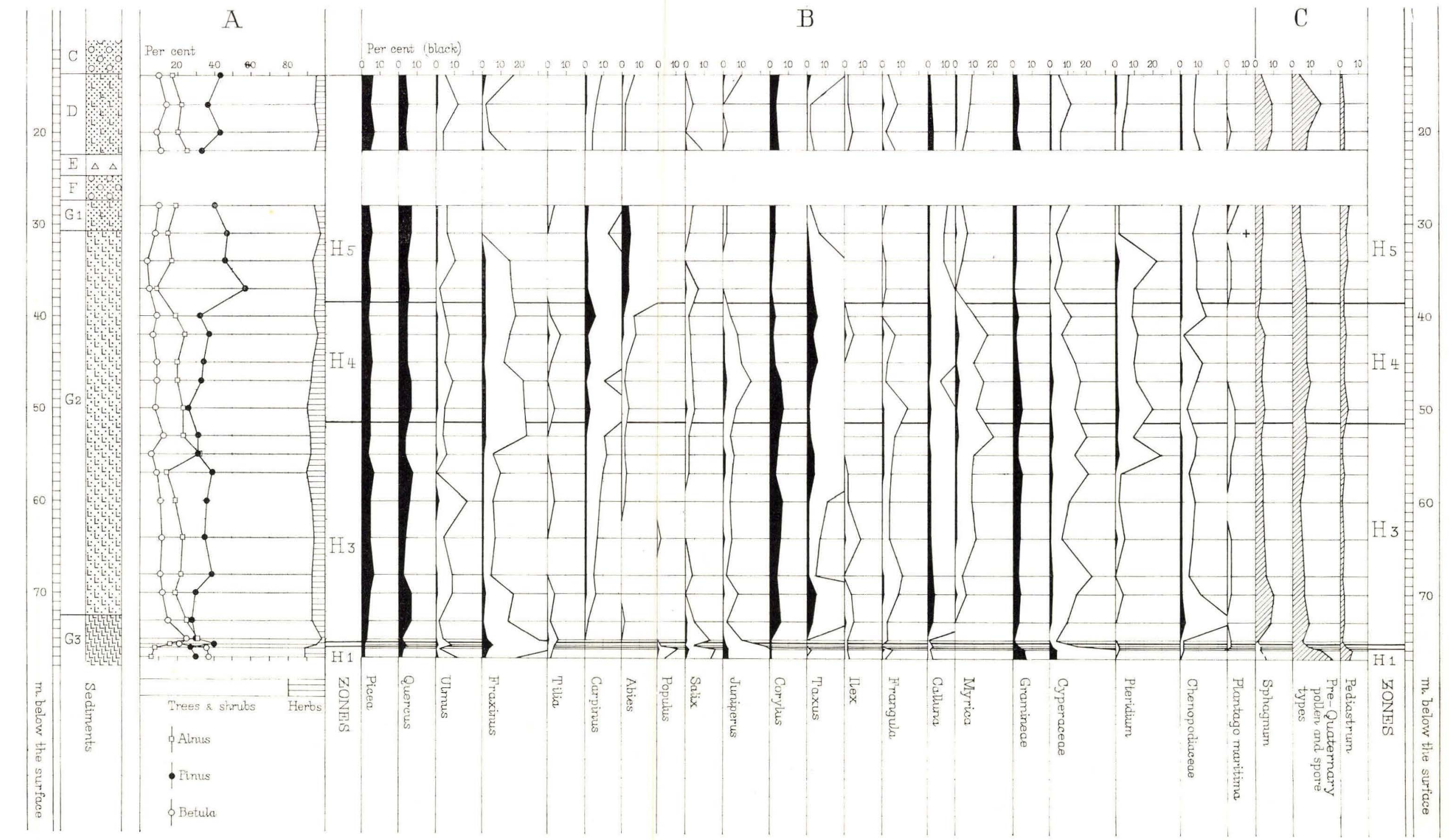

